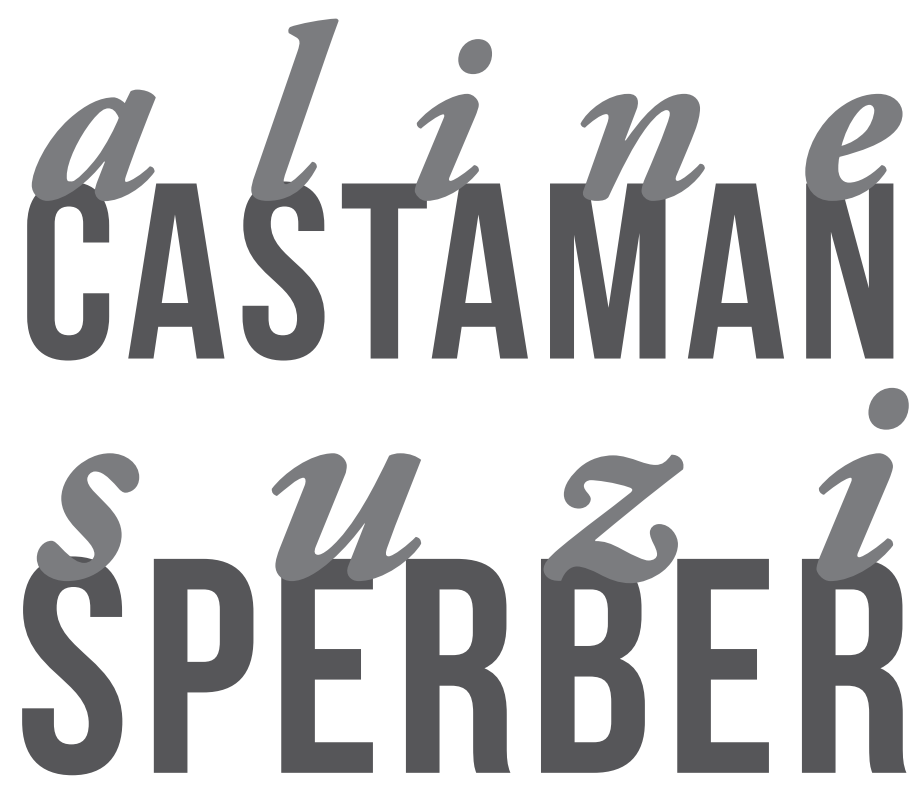

Universidade Estadual de Campinas (UNICAMP)

\title{
O QUE SE SABE SOBRE A PREPARAÇÃO DO ATOR PROFISSIONAL ELISABETANO E JACOBINO PARA CADA ESPETÁCULO?
}

RESUMO> O presente artigo apresenta um cotejo de três perspectivas distintas (Gurr, Stern e Astington) a respeito dos manuscritos responsáveis pela transposição das peças de poetas como William Shakespeare e Ben Jonhson, por exemplo, ao palco e sobre o modo de preparação dos atores de companhias profissionais elisabetanas e jacobinas. $\mathrm{O}$ intuito da pesquisa é refletir sobre o trabalho dos atores, que em princípio pareceriam ser constrangidos na sua criação, e discorrer sobre particularidades reveladas pelos documentos encontrados pelos estudiosos acima sobre a organização do espetáculo no período.

PALAVRAS-CHAVE> teatro contemporâneo; dramaturgia; intertextualidade 


\section{O QUE SE SABE SOBRE A PREPARAÇÃO DO ATOR PROFISSIONAL ELISABETANO E JACOBINO PARA CADA ESPETÁCULO?}

Ao que muitos documentos e estudos indicam, a figura do diretor, como nos foi legada a partir da acepçáo que ascendeu no século XIX, não permitiria que fizéssemos relaçóes com o modo de preparação das peças no tempo de Marlowe e Shakespeare. Essa hipótese decorre de não existir uma única pessoa conhecida na época dos citados autores que se destacasse pelo trabalho de montagem e que assinasse sua autoria. A reverência parecia ser direcionada aos poetas e, simultaneamente, aos grandes atores. Entretanto, a montagem de um espetáculo requer sempre uma ou mais pessoas que o organize a partir de diretrizes que o estruturem na transposição da peça ao palco. Acreditamos que no fim do século XVI e começo do século XVII não poderia ter sido diferente e é bastante provável que as companhias profissionais delegassem essa função de preparação dos espetáculos a pessoas habilidosas.

Esse homem habilidoso era tido como um chefe dos bastidores, chamado de 'conspirador cênico' ou plotter das peças dos poetas; também poderia ser responsável por algumas outras atividades importantes dentro da companhia. Fora conhecido como o escriba (plotter), o guarda-livros (book-keeper) e também como o ponto (prompter) do espetáculo. Era uma figura estratégica para qualquer companhia profissional, com seu olhar dentro e fora do palco, o qual se manteria atento às entradas e saídas dos atores de cena, às falas e deixas de cada personagem a partir do acesso que tinha a dois livros fundamentais: o Book e o Plot.

O Book ou authorized book ${ }^{3}$ seria o livro com as cenas e as personagens da peça, as falas ou diálogos cena a cena construídas. Esse

3 Este livro conteria o mesmo conteúdo do Book, ou ainda, e mais importante, conteria a assinatura do censor que garantia à companhia que o espetáculo pudesse ser apresentado, assim como todos aqueles que nele participariam.

1 Mestre em Artes Cênicas pelo Programa de Pós-Graduação em Artes Cênicas (PPGAC) da Universidade Federal do Rio Grande do Sul (UFRGS) (2013) e Doutoranda no Programa de Pós-Graduaçáo em Artes da Cena (PPGADC) na Universidade Estadual de Campinas (UNICAMP).

E-mail: alinecastaman@gmail.com

2 Suzi Frankl Sperber é professora titular e professora colaboradora da Universidade Estadual de Campinas. E-mail: sperbersuzi@hotmail.com.br detentor de tarefas primordiais teria em máos o referido documento 
durante e depois do espetáculo, o que o tornaria conhecido como o guarda-livros (book-keeper ou o book-holder ${ }^{4}$ ) da companhia. Era ele quem teria de proteger tal livro contra possíveis furtos, já que contaria com a assinatura do censor licenciando a peça a ser apresentada. Vale retomar algumas das informaçóes acima acerca do Book e refletir sobre elas. O autor escrevia a peça (a qual, neste sentido primitivo, é um escrito, ou uma escritura), que precisava ser submetida à censura reinante. Esta riscava ou criticava trechos, personagens, e o espetáculo precisaria obedecer a tais modificaçóes. O book-keeper ou o book-holder era o responsável pela obediência às rasuras impostas; ele, e não o autor do texto.

Também havia o Plot, como mencionamos, que seria a estrutura, o "roteiro", o plano de ação das entradas e saídas de cada ator a partir das deixas e a lista de atores com suas respectivas personagens. A pesquisadora inglesa Tiffany Stern, em Fazendo Shakespeare: as pressóes do palco a página ${ }^{5}(2004$, p. 88 ) propóe que o plotter administraria as entradas e saídas dos atores, especialmente as entradas, através do Plot. Se os atores se equivocassem, e mesmo que por instantes o palco ficasse desfalcado, era ele quem seria responsabilizado por não ter coordenado as instruçóes de forma eficaz.

Esses dois documentos eram transcriçóes oriundas da peça do poeta com objetivos diferentes que precisavam ser manuseados conjuntamente. O plotter mantinha esses livros de preparação da peça sob sua responsabilidade e poderia responder a qualquer dúvida a respeito da narrativa, bem como transcrever as falas de cada uma das personagens para serem entregues aos atores, manuscrito outro conhecido como part (parte) e sobre o qual discorreremos mais adiante. Sua tarefa "árdua”, como o considera Stern (2009, p. 222), consistia em manter o espetáculo em andamento, assegurar que os atores fossem chamados ${ }^{6}$ a tempo de se prepararem para entrar em cena, ao mesmo tempo em que servia de ponto aos que estavam em cena, orientando os atores quando estes perdiam uma deixa ou outra de suas falas.
4 Como sua função principal era a de servir de ponto aos atores, o verbo 'segurar o livro' tornara-se 'servir de ponto a'. ('To hold the book' came to mean 'to prompt'. (STERN, 2009, p. 222)
5 Making Shakespeare: the pressures from stage to page. Tradução da autora.
6 Call/Called/Calling/Quoted, termo relevante no período elisabetano pois, segundo Stern (2009, p. 222), rememora a participação de ajudantes nos bastidores, meninos que corriam de um lado a outro para avisar das entradas dos atores um pouco antes de se posicionarem no palco para efetivá-las. Eles também ficariam em frente da casa de espetáculo para buscar os assentos, almofadas e água para os membros da audiência. Reza a lenda que Shakespeare teria entrado no universo teatral como um prompter's boy ou call-boy ou prompter's attendant. (STERN, 2009, p. 223) 
Para o especialista Andrew Gurr ${ }^{7}$, em O Palco Shakespeariano, 1574-1642 (2009), o plotter deveria estar familiarizado com o texto completo da peça e ter autoridade para tomar decisóes quando necessário, ou seja, um assistente precioso às voltas de Shakespeare, por exemplo,

[...] para ver se os atores estavam prontos em suas deixas, e para ter os acessórios em mãos, por carregá-los e reconhecer como e quando eles seriam necessários. $\mathrm{O}$ guarda-livros também era responsável, presumivelmente em discussão com os sócios da companhia, em distribuir os papéis ou partes aos atores o qual teria transcrito a eles. Ele teve diversos assistentes de palco para ajudá-lo, que também serviam de figurantes. (GURR, 2009, p. 254)
7 The Shakespearean Stage, 15741642.

Assim como Gurr (2004, p. 100/2009, p. 254), Stern (2004, 88) também sugere que havia mais de uma pessoa além do plotter ajudando nos bastidores, como funcionários que estariam sob sua orientação, e também os responsáveis pela preparação que antecede o espetáculo. Suas funções, por mais que distintas em sua hierarquia, eram relevantes e similares no que concerne à rotina de trabalho, seja ajudando na cópia do authorized book para garantir sua licença, seja na preparação dos Plots, ou na atenção dada aos atores, seus acessórios e figurinos. Compreendemos que apenas uma mão no comando do espetáculo fora inexistente, mesmo pelo plotterlbook-keeper/prompter mais obstinado em conjeturar soluçóes. Porém, decisões sempre tiveram de ser tomadas e teria sido o plotter, o integrante engenhoso, com autoridade conjunta com os atores líderes para tomar decisóes quando problemas emergiam antes e durante o espetáculo.

Apresentar peças diferentes durante seis dias na semana é uma particularidade que impressiona qualquer um que esteja familiarizado com os esforços empenhados na montagem de um espetáculo, onde quer que ocorra, na época que for. $\mathrm{E}$ no que concerne ao teatro elisabetano, nada poderia ter moldado a natureza da representaçáo melhor do que ter de se apresentar todos os dias, preparar peças novas nos intervalos habituais e confiar na memória 
de seus atores uma vez que "interpretavam quarenta diferentes personagens durante a temporada anual” (GURR, 2009, p. 124).

Quinzenalmente, novas peças eram encaixadas no repertório e reunióes deveriam ser realizadas entre o plotter e os atores líderes com o intuito de selecionar o elenco da peça, estruturar os Plots, distribuir as partes com as falas e deixas aos atores, construir a lista dos objetos necessários e determinar os pormenores mais imediatos a serem postos em prática. Tais características podem ser observadas no primeiro ato de Sonho de uma noite de verão, em que Cunha ou o plotter da peça se propóe o responsável por algumas tarefas, vejamos:

Cunha - Mas mestres, aqui vocês têm: os seus papéis. E eu devo pedir, solicitar, implorar que os senhores os estudem até amanhã à noite. Venham encontrar-me no bosque junto ao palácio, uma milha distante da cidade, à luz do luar. Ali ensaiaremos, pois, se nos encontrarmos, é certo que vão nos seguir e nos cercar, e nosso projeto não mais será segredo. Neste meio tempo, redigirei uma lista, com os adereços de que nossa peça necessita. Rogo-lhes: não me desapontem. (SHAKESPEARE, 2001, p. 25)

Essa estrutura da peça dentro da peça, do modo como fora apresentada por Shakespeare em Sonho de uma noite de verão, faz referência às companhias amadoras e pequenas que tinham de se adaptar ao seu pouco pessoal para montar um espetáculo. Retrata, em meados da década de 1590, um modelo obsoleto de representação no apogeu do teatro elisabetano, que é quando fora escrita. No entanto, esta recomendação apresenta algumas peculiaridades associadas às responsabilidades que supostamente se estenderiam ao plotter, tais como: a distribuição dos papéis aos atores, a entrega das parts com as transcriçóes das falas para que cada um as estudasse, o agendamento do encontro coletivo seguinte, e, por fim, a organizaçáo da lista de objetos que se fariam necessários para a apresentação da peça.

As parts, depois de entregues aos atores, como a personagem Cunha acima sugere, seriam manuscritos criados a partir do Book contendo somente as falas referentes às personagens, pois a transcrição 
da versão completa da peça para todos os atores seria impossível por algumas razóes que valem ser notadas. Uma diz respeito à questáo do tempo escasso entre um espetáculo e outro para o plotter transcrever a punho e à pena todo o conteúdo relativo às personagens para cada um dos atores que participaria do espetáculo -e que poderia se estender até doze atores; a outra se refere ao cuidado do plotter em gerar o mínimo de cópias dos diálogos de modo a assegurar que elas não caíssem em mãos alheias, o que viabilizaria a montagem por outra companhia.

As funçóes cumulativas do plotter dentro das companhias profissionais, a montagem do espetáculo a partir do Book, do Plot e da transcrição das parts são particularidades pontuais a respeito da montagem do espetáculo no período elisabetano. As peças compostas pelos poetas eram articuladas, pensadas para se transformarem em representação cênica. As ediçóes das peças feitas muito posteriormente para serem vendidas nas bancas não contemplam genuinamente o que teria sido realizado no decorrer da organização. A palavra montagem parece aqui ser propícia e adequada para classificar o modo de trabalho das companhias, pois que o espetáculo teria sido o resultado da reunião de etapas, uma engrenagem que fora documentada à parte nesses livros e que correspondiam aos aspectos práticos envolvidos na preparação. Esses documentos foram subtraídos das ediçóes das peças a que temos acesso atualmente nas prateleiras das livrarias e bibliotecas, e, portanto, tais ediçóes se tornam comprometidas e estarão sempre em dívida com o que fora a montagem de um espetáculo no período. Ou seja, a "peça” era composta por diferentes documentos que, compilados, formariam a unidade do espetáculo. Somente depois seriam editados, priorizando apenas o fluxo da narrativa da história.

Não é intrigante imaginar a concretização desse espetáculo que depende da (re)criação da unidade da história pelos atores apenas através das parts e não pelo texto completo? Como já mencionado, esses manuscritos eram documentos pessoais dos atores que continham apenas as falas correspondentes às personagens com as deixas de entradas e saídas. De acordo com Stern (2004, p. 123-5), 
cada ator receberia aquilo que era para ser falado e as deixas associadas a cada fala. No palco, ele as escutaria e daria seguimento às linhas dos diálogos que aprendera na ordem exigida e que se estabelecia entre os atores através das deixas, as quais eram curtas -máximo de três palavras- que precisavam ser cuidadosamente empregadas, assim como ouvidas pelos atores nas coxias. A part não tinha uma relação forte com a história em termos narrativos, o que nos remete a pensar que a noção dos atores com relação ao todo da história era vaga. Além disso, Stern (2004, p. 129) infere que é muito possível que, se modificações nos diálogos de uma ou outra personagem tivessem ocorrido no decorrer de preparação, elas seriam apenas repassadas aos atores correspondentes. Logo, os atores pouco ou nada saberiam do conteúdo das falas das personagens de seus parceiros de cena, bem como aquilo que seria dito para e sobre a personagem talvez não chegasse ao conhecimento do ator.

A partir das colocaçóes de Gurr e Stern ao longo deste estudo, foi possível constatar que a noção de unidade da peça não teria existido para os atores até o momento em que o espetáculo se realizasse. É muito provável que reformulaçôes, ajustes - mesmo que mínimos-faziam parte do processo de escritura durante o período de preparação do espetáculo e posteriormente, quando reapresentados. Mas, segundo esses estudiosos, os manuscritos legados transmitem quase nada daquilo que teria sido a representação da peça, e mais, assinalam seu potencial intrínseco.

Isso aponta a fragilidade do conteúdo desses documentos que comunicam inexatamente, mas potencialmente, o que seria um espetáculo apresentado pelos atores das companhias profissionais elisabetanas. Para Stern (2009, p. 238), o problema estaria associado à duvidosa e polêmica origem das parts. A especialista afirma que, se quisermos examinar quais são e onde as diferenças entre parte e peça poderiam ocorrer, seria necessário comparar os papéis que restaram dos atores com as peças completas nas quais esses papéis estavam inseridos. Em última instância, esses papéis seriam os responsáveis, afinal, pela representação da peça no palco. Seriam eles que forneceriam o que havia sido, em potencial, transposto à cena. 
Pelo que sabemos, parte e peça não só teriam sido escritos em épocas diferentes como por pessoas diferentes e comunicavam coisas distintas. Nem todas as instruçóes foram compartilhadas entre peça e parte; cada uma fornece informações através de expressóes levemente diferentes e que se adéquam ao tipo de documento e à sua finalidade. Stern (2009, p. 239) é mordaz em afirmar que cada documento possui instruçóes relevantes ao tipo de manuscrito que representa e não há como assegurar de qual livro esses papéis teriam se originado. Seria do Book ou da peça completa entregue pelas mãos do poeta? Seu argumento está fundamentado na diversidade de cópias oriundas da fonte do poeta e da narrativa da história da peça. Suas conclusôes se direcionam para uma afirmação conciliadora, mas não definitiva. Seria de algum livro que pode ter se tornado o livro do ponto (prompter's book) e que serviria para a preparação do espetáculo. Cada parte individual teria sido mediada por alguém que não tinha o objetivo de, ou não precisava, ser completamente fiel à peça. Poderia ter sido o poeta, ou o prompter/plotter, e até mesmo um ator quem teria feito as transcriçóes aos seus parceiros de cena. E não havia razão para copiar a linha de um diálogo da peça tão fielmente quando era sabido, por exemplo, que os próprios atores poderiam empregar outras expressóes que se aproximariam do sentido inicial.

Porém, Gurr (2009) já propóe uma abertura menos ampla e arriscamos, inicialmente, afirmar, mais consistente do que a noção de Stern, pois confere ao authorized book uma importância chave a respeito de tantas escrituras e polêmicas. Esse documento seria o texto máximo, nas mãos da companhia, e, que, portanto, o espetáculo poderia e deveria ser preparado a partir dele (GURR, 2009, p. 122). É uma assertiva que se fundamenta no fato de o documento ter sido sine qua non às apresentaçóes, o único documento que verdadeiramente conferia à companhia autoridade para poder intervir nele, preparar o espetáculo, e transcrever os diálogos para seus atores. $\mathrm{O}$ único documento de que se pode afirmar que com certeza asseguraria a representação da peça, pois conteria a autorização daquilo que seria permitido falar no palco e de quem as falaria (GURR, 2009, p. 1323). 
Constatado isso a partir das investigaçôes minuciosas desses dois grandes especialistas, Gurr e Stern, os quais se debruçaram sobre os manuscritos originais, passamos, digamos, da teoria à prática no tocante à questáo que envolve diretamente o trabalho dos atores: a preparação de seus papéis rumo à apresentação do espetáculo a partir das parts. Conforme Stern (2004, p. 64), elas seriam o produto final dos poetas, nas mãos dos atores, antes de estes entrarem em cena. Teriam sido o testemunho único do tipo de trabalho desenvolvido pelos atores e eram ricamente obscuras, porém, suficientes para que eles subissem ao palco e realizassem o espetáculo.

São manuscritos, escrituras, documentos que, analisados por Gurr e Stern, parecem demonstrar que a obscuridade é apenas o reflexo da limitada compreensão dos documentos que se encontram diante deles, uma vez que a preparação dos atores para o espetáculo, já estudada cada pequena part, parece ter sido completa. A quantidade e os tipos de papéis que os atores representavam dentro do sistema de repertório, tanto do Globe Theatre, como de outros teatros, e o tempo restrito disponibilizado a aprender ou reaprender as linhas das personagens entre um espetáculo e outro fundamentaram a prática de preparação dos atores através de anotaçôes escritas. No final, eram eles os responsáveis por transpor a peça ao palco.

Os atores lidavam com uma quantia substancial de linhas de texto/s que tinham de aprender e/ou reaprender ${ }^{8}$. A preparação dos papéis, conhecida como private study (estudo privado), estaria 8 Learn and relearn - aprender, estudar, fixar na memória. associada a um sistema de aprendizado estabelecido ao longo de anos e que se manteve como referência pelo menos até 1642. Nesse sistema, os atores poderiam ser tanto instruídos por outros atores, mestres, poetas ou tutores, ou reaprenderiam individualmente. A instruçáo que um ator recebia de outro ator, ou de um mestre ou tutor, permanecia como lei e deveria continuar sendo transmitida ao seu substituto e da mesma maneira aos sucessores. Curiosamente, o aprendizado era um sistema legalmente reconhecido em qualquer tipo de ocupação ou trabalho, e a regulação teria sido estabelecida no início do período elisabetano pelo Estatuto dos artesãos em 1563. Os atores, por exemplo, legalmente vinculados como aprendizes às 
companhias profissionais, possuíam um termo que se estendia por pouco mais de sete anos.

Para outro grande estudioso, John Astington, em Atores e Interpretação nos tempos de Shakespeare: a arte de representar ${ }^{9}$ (2010, p. 4 ), cada ator teria um período curto de aprendizado, que se estendia da adolescência ao início da idade adulta -dos 14 aos 24 anos. Nem todos os atores, porém, se iniciaram meninos ou adolescentes na arte teatral, como também é claro que nem todos os meninos que foram aprendizes continuaram a trabalhar como atores quando se tornaram adultos.

Seja para o aprendiz, seja para o profissional, estudar um papel significava aprendê-lo, a saber, o ator dizer todas as suas falas correta e pontualmente, nas deixas dramáticas apropriadas e na ordem certa. Logo, os atores teriam de saber suas deixas de cor, tanto as que diziam respeito a sua vez de interpretar, como também na função de retribuí-las, sendo precisos, em suas falas, para que os outros atores pudessem dar continuidade ao andamento do espetáculo. Segundo Astington (2010, p. 141), “dar uma deixa era tão importante quanto receber uma”. Outra vez, o ato primeiro de Sonho de uma noite de verão continua tendo muito a nos oferecer. Neste caso, a ênfase está sobre a inabilidade dos atores em se ajustar ao sistema de deixas. Vejamos,
9 Actors and Acting in Shakespeare's

Time: the art of stage playing.

Cunha - Fale, Píramo; Tisbe, venha para a frente.

Fundilho - As doces flores, Tisbe, de sabores amoráticos...

Cunha - "Aromáticos!", "aromáticos!”

Fundilho - ... de sabores aromáticos; Têm o mesmo perfume, Tisbe, de teu doce

hálito, Minha amada Tisbe querida. Mas, escuta, uma voz! Fica aqui, e num instante eu volto para ti.

Bute - Jamais aqui, jamais antes, encenou-se um Píramo tão estranho!

Flauta - Preciso eu falar agora?

Cunha - Sim, pela Virgem Maria, você precisa. Você 
precisa entender que ele vai verificar um barulho que ouviu e deve retornar logo.

Flauta - Alvo como um branco lírio é o radiante e belo Píramo, Um jovem muito adorável, um Juvenal tão vívido, Corado igual rubra rosa de triunfante urze branca, como cavalo correto e leal que náo se cansa; contigo encontrarei, Píramo, no túmulo de meninos.

Cunha - "Túmulo de Ninus", homem! Mas, ora, você não deve falar isso agora; essa é a sua resposta a Píramo. Você está falando toda a sua parte de uma vez só, deixas e tudo! - Píramo, entre! Sua deixa já passou; é "que não se cansa”.

Flauta - ah...Como cavalo correto e leal que não se cansa (SHAKESPEARE, 2001, p. 50).

Vemos que importante era aprender de cor completa e perfeitamente o texto referente a cada papel -e também as deixastanto importantes para que cada ator não errasse o momento de sua intervenção, como para que soubesse onde parava cada fala. A concepção de que o conhecimento total, completo da peça era fundamental faz supor que cada ator assim se sentiria mais livre e pleno para a sua interpretação -a saber, para a sua ação em cena. Ao contrário dos atores amadores que aprendiam o sistema dentro da própria prática, houve, no teatro profissional, esses tais instrutores para ajudar os atores em seu processo de aprendizagem. Os instrutores dos atores meninos e atores contratados eram os atores superiores e no caso dos atores superiores, era o próprio poeta com uma sugestão a esse ator profissional. E o que, precisamente, era estabelecido durante as instruçóes era aquilo que o ator diria e faria. Aparentemente, os atores não estavam primeiramente preocupados com a história que estavam contando, e sim, em estudar cada parte, suas deixas e falas. As intervençôes de Cunha parecem vir de um conhecimento do todo, adequando cada parte dos papéis dos atores a seu tempo e momento. Em parte, o humor da peça decorre dos quiproquós advindos da mistura fora de ordem da fala das personagens. E aponta para um aspecto que não vem sendo estudado: o da requerida memória dos atores na cena, visto que a memorização exata correspondia a um dos atributos positivos de cada ator. 
Uma vez estabelecido o modo de interpretação, o papel estaria fixado não apenas para aquela apresentação em particular, mas para todas as outras subsequentes. Atores novos sendo treinados para representarem determinados papéis eram ensinados a imitar precisamente a maneira em que o papel fora interpretado na sua primeira vez, o que para Stern (2004, p. 84) era um sistema muitas vezes ditatorial. Notamos aí certa inflexibilidade da autora, mas essa perspectiva surge em função de que mudanças no momento da representação parecem não ter sido muito bem-vindas. Para que possamos compreender um pouco mais sobre o que perpassa tal pensamento precisamos adentrar o universo da improvisação e suas implicaçóes.

Os clowns, por exemplo, com sua longa tradição na improvisação, eram providos de habilidades únicas, distintas do resto dos atores da companhia, por serem detentores de um repertório muito particular. Possuíam autoridade para improvisar quando urgente e necessário, especialmente nos entreatos, em algum eventual problema ou desfalque em cena, e também no final do espetáculo depois das peças trágicas. Como a improvisação era um elemento exterior às parts dos atores, vale lembrar que ela e todo e qualquer conteúdo modificado nas parts não seria oficialmente autorizado pelo censor. Fazer vista grossa às improvisaçóes e a tais ajustes parece ter sido uma adequaçáo conveniente para tantos espetáculos acontecendo ao mesmo tempo-lembrando que em 1600 a cidade de Londres possuía oito teatros e que os atores poderiam, eventualmente, trabalhar em mais de uma companhia... Os clowns teriam se distinguido por suas habilidades no tocante à improvisação em cena, porém esta era uma característica não muito bem recebida pelo poeta. Shakespeare, talvez avesso às excessivas improvisaçóes do famoso ator cômico de sua companhia William Kempe, parece expressar sua insatisfação no ato terceiro de A Tragédia de Hamlet, Príncipe da Dinamarca, com uma brincadeira curiosa e ácida nas palavras empregadas pela personagem-título ao se referir aos clowns de seu tempo. De acordo com Stern (2004, p.67), essa brincadeira talvez tenha sido direcionada especialmente a Kempe e/ou ao hábito 
de negligenciar o texto para improvisar além da conta em cena,

Hamlet - Oh, corrijam tudo! $\mathrm{E}$ não deixem os palhaços falarem mais do que é destinado a eles - que vai sempre ter um deles que vai rir [40] para fazer rir também quantidades de espectadores idiotas, embora, nesse mesmo momento, tenha alguma questão fundamental na peça para ser considerada. Isso é abominável, e revela uma ambição lamentável no idiota que usa dessas coisas. Vão se aprontar. [45] Saem Atores.

A atitude impaciente de Hamlet com relação às improvisações exageradas denuncia a reprimenda de Shakespeare aos atores que dizem mais do que deveriam em cena e peça trágicas -e não parece improvável ter sido esta crítica dirigida a Kempe. Um ator como ele, o último dos famosos clowns elisabetanos, como afirma Gurr (2009, p. 108), presente em quase todas as peças do repertório e com vasta experiência, teria saído em 1599 e é provável que sua ausência tenha sido sentida pelo público.

Kempe era mais conhecido pelo repertório de cançôes, pela arlequinada (harlequinade) e danças (jigs), por exemplo, do que por sua agudeza ou inteligência tão atribuída a Robert Armin, seu substituto em 1600. Há suposiçóes de que a saída de William Kempe esteja baseada na sua apropriação indevida da última publicação da peça As Alegres Comadres de Windsor, na qual interpretara Falstaff. Roubos eram recorrentes no período, e por isso era necessário proteger documentos e cópias de usurpadores (GURR, 2009, p. 108). E caso os atores fossem substituídos ou remanejados, as parts seriam imediatamente repassadas para serem estudadas pelos novos atores.

Mas nem tudo poderia ser estudado ou transmitido. A morte de um ator era lamentada em função do talento singular na interpretação de seus papéis. Ou seja, seria esse modo de interpretação vinculado a um sistema ditatorial, como infere Stern? Há, portanto, uma possibilidade outra que julgamos poder ampliar essa perspectiva e que está associada ao estudo privado e o aprofundamento do caráter 
das personagens.

A instrução que um ator recebia não envolvia discutir caráter ou motivo das personagens como conhecemos atualmente, mas envolvia outra forma de aprofundamento e que está associada ao entendimento que se tinha na época sobre a definição da arte de interpretar do ator: o Passionating. No aprendizado, um ator superior ou o próprio poeta recitava a parte ao ator "ocupando-se" do modo que deveria ser falado. Posteriormente, este ator deveria se concentrar em identificar as passions (paixôes) em cada part de sua personagem para manifestá-las apropriadamente. Dramaturgos, se envolvidos em alguma instrução individual, e mesmo instrutores, não tinham tempo nem oportunidade para ensinar todos os atores separadamente. Eram os atores que teriam de se dedicar, em seus estudos privados, ao Passionating. E como supõe Stern (2009, p.11), o modo como os atores recebiam e respondiam as suas parts teria tido um grande efeito no modo de conceber seus papéis. Portanto, a tarefa do ator implicava dar atenção aos gestos, às ênfases, e às paixóes exigidas em cada pequena parte, para que o todo não ficasse comprometido. Era isso que poderia ser preparado.

Arriscando-se mais que Stern (2004), Astington (2010) acredita que o estudo privado poderia revelar a habilidade do ator em aprofundar o caráter das personagens, pois segundo o autor, o termo abrangeria

a intenção, a imaginação, a experimentação e a autocensura pessoal do ator em trazer à tona o papel 'do texto' e transformá-lo em presença concebida; no tempo de Shakespeare, os atores teriam dado especial atençáo a este trabalho de forma individual, antes do período de ensaios do grupo necessariamente começar. Quão profundamente os atores poderiam ter estudado seus papéis teria dependido em parte da personagem e disciplina de cada ator [...] e da exigência do papel em si (ASTINGTON, 2010, p. 141).

$\mathrm{O}$ ator estudava mais do que uma sequência de palavras, que 
se pensa terem sido irrefletidamente pronunciadas como se ele fosse um ventríloquo. Cada ator, é muito provável, absorveria a história completa da peça que estaria representando no palco. Ele escutaria a história no momento da apresentação. Logo, Astington (2010, p. 187) sugere que a preparação individual do ator, qualquer que fosse a complexidade do papel, era inevitavelmente complementada por e sujeita a ajustes com toda a companhia dando energia e movimento, além de haver um determinante audível e responsável por aproximar o ator do todo da peça durante o acontecimento teatral e de enriquecer a interpretação.

Acreditamos que o tempo reduzido de estudo neste universo táo acelerado do entretenimento cênico, com peças diferentes sendo apresentadas de um dia para o outro, surpreenderia vez ou outra até mesmo os atores profissionais mais experientes com os temidos "brancos", mas que logo seriam arrematados pelo prompter, o qual se mantinha atento, ou pelo menos deveria se manter atento, às falas de seus atores. Esse modo de preparo das companhias profissionais em função do ritmo de trabalho bastante enérgico tornou-se um hábito arraigado entre os atores, sendo passado de geração a geração. Somado a isso, Astington (2010, p. 8) infere que o convívio dos artistas no subúrbio londrino, vivendo próximos uns aos outros, promovia que os atores se encontrassem e passassem suas falas com um ou outro ator, ou mesmo lessem em conjunto, ou mesmo tecessem comentários a respeito de personagens e peças. As casas dos atores ou alojamentos eram provavelmente utilizadas para essas pequenas reuniōes de preparação profissional.

Essa abertura ou flexibilidade, no pensamento de Astington (2010), a respeito do aprofundamento do papel é distinta das consideraçóes de Stern (2004). Para Stern (2004, p. 84), um papel, uma vez aprendido, estava supostamente fixado. Quando um ator se tornava muito velho para interpretar seu papel, ele o entregava literalmente ao seu sucessor. Ele passava ao seu sucessor a parte escrita e ensinava o modo "correto" de falar e agir -as ênfases e os gestos. $\mathrm{O}$ novo ator seria dimensionado e escolhido por sua habilidade em imitar o antigo: qualquer coisa que ele alterasse era 
provavelmente censurada. Os papéis continuavam sendo passados de um ator a outro exatamente da mesma maneira, com os maneirismos aprendidos e reproduzidos ao longo de duzentos anos. Os textos separados dos atores, de acordo com Stern (2004, p. 84), continham toda a informação necessária para aquele ator interpretar bem seu papel. $\mathrm{E}$ os atores náo teriam sido livres para atuar como bem o desejassem. Eles eram livres somente para atuar da maneira como o texto desejava que eles o fizessem -com a ajuda de supervisores que os instruiriam a interpretar as demandas do texto.

De uma forma ou de outra, os atores juntavam todas as suas parts e, no final, a peça tinha de funcionar no palco. Receber seu texto e interpretá-lo, do modo como fora descrito acima, significava que os atores nunca perdiam o sentido de "parte". Stern (2004, p. 89) infere que há, por exemplo, indicações de que era comum, durante a apresentação ou mesmo dentro da esfera de ação, o ator não manter a personagem, enquanto o outro ator estava interpretando. A autora refere-se a uma eventual quebra de unidade da peça decorrente da quebra de ação dos atores. É que a unidade era assegurada pela história da peça, no momento do espetáculo. E, em consequência da noção de parte tão forte e viva, dentro do referido sistema de repertório, e da preparação dos atores bastante intensamente construída em cima das partes, algum ator poderia distrair-se em momentos de sua presença sem falas em cena. A potência de uma encenação e a força de um espetáculo dependem da intensidade de cada presença em cena. A distração, ou "ausência" de algum ator, poderia comprometer o todo.

Uma combinação de fatores, portanto, fundamenta esse sistema de trabalho tão complexo. A era de Shakespeare contou com atores que, meninos ou homens, eram instruídos, iniciados na literatura, e providos de boa memória -exigência primordial para o ator elisabetano, uma vez que havia muitos papéis para aprender àquele que quisesse entrar em uma companhia profissional com um repertório variado. Os atores deveriam conhecer bem a língua e a literatura, e é muito provável que estivessem atentos às peças que estavam sendo escritas e encenadas nos palcos públicos pelas companhias rivais. Atores que também eram escritores estavam a 
par das peças que eram apresentadas. E embora as apresentąçóes diárias tivessem deixado pouco tempo livre para os atores, Astington (2010, p. 8) acredita que quando uma chance se oportunizara, eles teriam ido assistir aos colegas de profissão nas casas de espetáculos vizinhas, com um olhar crítico às fragilidades e às superioridades na interpretação de seus pares.

Parece razoável pensar que, por volta de 1600, uma comunidade estabelecida de artistas vivia na cidade de Londres, nos mesmos arredores, e a maioria deles se conhecia. Gerações e gerações de atores aperfeiçoariam o gene artístico, culminando em talentosos atores que se profissionalizaram e conquistaram um espaço fixo em Londres entre os séculos XVI e XVII. O ator elisabetano, considerado por Astington (2010, p. 108) como hábil ou competente, deveria dominar uma série de papéis. Esse ator, o qual se apresentava diariamente durante a temporada, teria pouco tempo para aprender e reaprender suas "linhas", ou oportunidade para aprofundar as questóes de motivação de sua personagem. Contaria com boa memória, com a capacidade de transitar entre os gêneros cômico e trágico, ou se especializaria num tipo para conquistar um lugar permanente numa companhia. Era também um ginasta e esgrimista que se via desafiado diante de uma audiência crítica e saliente, pronta e a postos para atirar tomates quando suas cenas não eram bem preparadas e coreografadas.

As companhias adultas do período elisabetano eram suficientemente capazes de montar espetáculos de um dia para o outro, no caso de reapresentaçóes, e de duas a três semanas para aqueles roteiros recém-adquiridos. A ideia de que os atores dispunham de poucas horas para se preparar, em época de temporada, é bastante intrigante, pois eles teriam apenas uma parte do dia para aprenderem ou reestudarem seus papéis para subirem ao palco. Isso nos faz refletir sobre as prioridades da companhia, em função do ritmo de trabalho na maior cidade europeia de entretenimento. No entanto, náo subtraímos a capacidade de interação entre os atores, pois, por mais que o ator não tivesse todo o texto, estariam cientes do comportamento das personagens, limitados pela hierarquia dessas, 
pelo tom e discurso do outro, e responderiam a isso enriquecendo a interpretação à sua maneira, que vai além de técnicas e tradiçôes ditatoriais.

Através da pesquisa, percebemos que a preparação do ator profissional elisabetano, que fora instruída e guiada pela própria dramaturgia e retórica no sentido da elocução, ou no estudo do papel calcado numa tradição de transmissão que o ator precisava dominar, se apresentou muito mais complexa do que apenas imitar o ator precedente, o qual tinha interpretado pela primeira vez determinado papel. Afinal, eram os atores os responsáveis em preparar as personagens de Shakespeare ou Marlowe, a externar a partir de suas parts o universo complexo de homens e dos vários estados de suas mentes.

\section{REFERÊNCIAS BIBLIOGRÁFICAS:}

ASTINGTON, John H. Actors and Acting in Shakespeare's Time: the art of stage playing. Cambridge University Press, 2010.

GURR, Andrew. The Shakespearean Stage, 1574-1642 - $4^{\text {th }}$ ed. Cambridge University Press, 2009.

. The Shakespeare Company, 1594-1642. $1^{\text {st }} \mathrm{ed}$.

Cambridge University Press, 2004.

SHAKESPEARE, William. A tragédia de Hamlet, Príncipe da Dinamarca. Tradução de Lawrence Flores Pereira. São Paulo, Editora 34, 2008.

. Sonho de uma Noite de Verão.

Tradução de Beatriz Viégas-Faria. Porto Alegre, L\&PM, 2001.

STERN, Tiffany. Making Shakespeare, the pressures of stage to page.

Routledge, NY, New York, 2004. 
Documents of Performance in Early Modern

England. Cambridge University Press. Printed in the UK, 2009.

\section{ABSTRACT}

This paper presents a comparison between three different perspectives (Gurr, Stern and Astington) related to the manuscripts which were responsible for the transposition of plays written by William Shakespeare and Ben Johnson, for example, to the stage on the ways of preparation used by the actors in the Elizabethan and Jacobean professional companies. The aim of the research is to think about the work of the actors, which in principle, would seem to be constrained in their creation, and discuss peculiarities, revealed by the documents, related to the organization of the scene in the period.

\section{KEYWORDS}

Elizabethan and Jacobean Professional Actors; Preparation; Manuscripts. 